\title{
Pengaruh Penerapan Media Pembelajaran Interaktif MONIPA Terhadap Hasil Belajar Nilai Nilai Pancasila Dalam Kehidupan Sehari-hari di Kelas VI SDN I Keresek.
}

\author{
Uun Hasanah ${ }^{1}$, Omin $^{2}$, Nuraeni $^{3}$ \\ Program Studi Teknologi Pendidikan, Sekolah Pascasarjana \\ Institut Pendidikan Indonesia, Garut \\ Email :uunhasanah94@gmail.com,ominermin@gmail.com,nurnuraeni846@gmail.com,
}

\begin{abstract}
Abstrak. Siswa sekolah dasar masih berpikiran konkret sehungga kegiatan pembelajaran di sekolah tidak bisa lepas dari penggunaan multimedia pembelajaran.Penelitian ini bertujuan untuk meningkatkan pemahaman nilai-nilai Pancasila dan meningkatkan prestasi belajar PKn melalui penerapan model pembelajaran cooperative learning dengan menggunakan media pembelajaran MONIPA Penelitian ini menggunakan metode penelitian tindakan kelas dengan melalui dua siklus. Hasil penelitian menunjukkan bahwa: (1) Metode cooperative learning dengan media MONIPA dapat meningkatkan pemahaman materi nilai-nilai Pancasila siswa kelas VI di SDN I Keresek. (2) Peningkatan taraf keberhasilan hasil belajar pada aspek pemahaman materi pada siklus pertama ke siklus kedua sebesar 59,58\% dengan tingkat keberhasilan pada siklus pertama sebesar 31,9\% dan tingkat keberhasilan pada siklus 2 sebesar 91,48\%. Selanjutnya, hasil penelitian ini diharapkan mampu meningkatkan pemahaman materi nilai-nilai pancasila secara terus menerus di SDN I Keresek.
\end{abstract}

Kata Kunci: Media MONIPA, Hasil Belajar, Nilai-nilai Pancasil 
Jurnal Ilmiah Mandala Education

http://ejournal.mandalanursa.org/index.php/JIME/index

terakreditasi Peringkat 4 (No. SK: 36/E/KPT/2019)

\section{PENDAHULUAN}

\section{Latar Belakang Masalah}

Pendidikan adalah suatu kekuatan dinamis dalam kehidupan setiap individu, yang mempengaruhi perkembangan fisik, daya jiwa (akal, rasa, dan kehendak), sosial dan moralitasnya (Dwi Siswoyo, 2007:53). Melalui pendidikan, seorang anak akan mendapat pengalaman dan ilmu pengetahuan sebagai bekal untuk masa depannya. Anak dapat mengembangkan potensi yang ada dalam dirinya untuk dapat memiliki ketrampilan yang diperlukan untuk dirinya, masyarakat, bangsa dan negaranya.

Sekolah merupakan suatu lembaga pendidikan yang memiliki wewenang untuk mendidik siswa dalam membantu pertumbuhan dan perkembangannya, selain orang tua di lingkungan rumah. Pertumbuhan dan pe dan perkembangan pada masa anak-anak memang diperlukan sejak dini melalui pendidikan dasar. Suharjo (2006: 1) mengatakan bahwa sekolah dasar merupakan lembaga pendidikan yang menyelenggarakan program enam tahun bagi siswa usia 6 - 12 tahun, untuk memberikan bekal kemampuan dasar pada siswa berupa pengetahuan, ketrampilan dan sikap yang bermanfaat bagi siswa sesuai tingkat perkembangannya.

Dari pengalaman peneliti ada dua masalah yang sering dijumpai dalam pembelajaran khususnya pelajaran PKn, dimana aktifitas siswa dan hasil belajar siswa rendah, penyebab aktifitas siswa rendah antara lain metode pembelajaran yang tidak melibatkan aktifitas siswa secara utuh, sehingga siswa belajar hanya menghafal, selanjutnya hapalan itu akan hilang karena kegiatan menghafal bukan hal yang mudah menurut Negoro,S.T dan harahap,B. (1984). Menurut Corey dalam tileston,D.W.(2007) bahwa belajar adalah sebuah proses yang sangat berbeda dengan kegiatan memperhatikan.dan hasil belajar siswa rendah karena guru tidak menggunakan media dalam pembelajaran sehingga siswa tidak memahami materi pembelajaran dan otomatis hasil belajar siswa akan rendah.
Hal ini sejalan dari sekolah yang sedang diteliti di SDN I Keresek Kecamatan Cibatu Kabupaten Garut kelas VI yaitu mengalami hasil belajar belajar yang selalu rendah dan pemahaman siswa lemah dalam pelajaran PKn dari jumlah siswa 47 orang yang berhasil sesuai KKM adalah $31,9 \%$ tuntas dalam siklus I dan $91,48 \%$ tuntas pada siklus II.

Dari dua masalah tersebut peneliti akan mempfokuskan masalah hasil belajar,karena hasil belajar adalah indikator keberhasilan siswa mempelajari PKn. Untuk memecahkan masalah dan meningkatkan hasil belajar siswa peneliti mencoba menggunakan media pembelajaran MONIPA. Alat peraga atau media pembelajaran MONIPA ini menggunakan alat sederhana yang mudah didapat dan mudah dibuat serta murah harganya tetapi sangat besar manfaatnya.

\section{Identifikasi Masalah}

Berdasarkan latar belakang masalah, maka dapat diidentifikasi diidentifikasikan masalahnya sebagai berikut :Bahwa rendahnya hasil belajar siswa karena guru dalam menyampaikan materi tidak menggunakan alat peraga sehingga siswa tidak tidak mengerti materi yang diberikan guru dan ada sebagian guru yang kurang mengetahui pentingnya memotivasi siswa untuk belajar.

\section{Batasan Masalah}

Ruang lingkup dan fokus masalah dalam penelitian ini hanya terbatas pada rendahnya pemahaman dan hasil belajar siswa serta motivasi belajar siswa. Ketiganya merupakan obyek penelitian. Subjek penelitian hanya terbatas pada siswa kelas VI SD Negeri I Keresek.

\section{Rumusan Masalah}

Berdasarkan identifikasi masalah yang telah diuraikan maka diajukan rumusan masalahnya nyaitu,

1. Apakah alat peraga MONIPA dapat meningkatkan pemahaman siswa pada materi Nilai-nilai pancasila dalam kehidupan sehari-hari di SDN I Keresek?’.

2. Bagaimana alat peraga MONIPA dapat meningkatkan hasil belajar siswa pada 
materi Nilai-Nilai pancasila dalam kehidupan sehari-hari di SDN I Keresek?.

3. Apakah alat peraga MONIPA dapat meningkatkan keaktifan peserta didik kelas VI SDN I Keresek pada materi Nilai-Nilai pancasila dalam kehidupan sehari-hari?.

\section{Tujuan Penelitian}

Tujuan penelitian ini adalah sebagai berikut:

1. Untuk meningkatkan pemahaman peserta didik terhadap materi Nilai-Nilai Pancasila dalam kehidupan sehari-hari.

2. Untuk meningkatkan hasil belajar peserta didik terhadap materi Nilai-Nilai Pancasila dalam kehidupan sehari-hari.

3. Untuk mengaktifkan / respon peserta didik dalam kegiatan pembelajaran

\section{Manfaat Penelitian}

Dengan menggunakan alat peraga MONIPA pelaksanaan penelitian ini diharapkan dapat memberikan manfaaat kepada:

1. Siswa

a. Dapat meningkatkan pemahaman dan hasil belajar siswa dalam menyelesaikan soal Nilai -Nilai pancasila dalam kehidupan sehari-hari.

b. Dapat menghilangkan image tentang sulitnya belajar PKn

c. Akan lebih termotivasi untuk belajar PKn.

2. Guru

a. Guru dapat lebih cepat mengetahui kesulitan belajar siswa.

b. Menambah kreativitas guru untuk menerapkan pembelajaran yang bervariasi.

c. Menambah wawasan dalam menyelenggarakan proses pembelajaran dengan menggunakan alat peraga.

3. Sekolah

Dengan membuat alat peraga MONIPA diharapkan dapat menerapkan model pembelajaran bervariasi dan dapat memanfaatkan barang barang sederhana atau barang bekas menjadi media pembelajaran sebagai alat peraga yang murah dan mudah didapat. Sehingga meningkatkan proses pembelajaran dan prestasi siswa sehingga kualitas sekolah semakin baik.

\section{KAJIAN TEORI Kajian Teori}

Alat peraga pendidikan adalah suatu alat yang dapat diserap oleh mata dan telinga dengan tujuan membantu guru agar proses belajar mengajar siswa lebih efektif dan efisien" (Sudjana, 2009). Sedangkan (Wijaya, 2000) menyebutkan bahwa "alat peraga pendidikan adalah media pendidikan yang berperan sebagai perangsang belajar dan dapat menumbuhkan motivasi belajar sehingga siswa tidak menjadi bosan dalam meraih tujuan-tujuan belajar.

Menurut kedua pendapat ahli di atas jelas dinyatakan bahwa untuk membantu guru dalam usaha mencapai tujuan-tujuan belajar yang diharapkan diperlukan alat bantu (media). Jadi alat peraga sangat penting keberadaannya untuk meringankan kinerja guru dalam kegiatan pembelajaran. Terlebih pembelajaran matematika. Hal ini karena konsep matematika yang abstrak sehingga diperlukan adanya alat peraga sebagai jembatan bagi siswa untuk memahaminya. Khususnya bagi siswa SD yang masih dalam tahapan berpikir konkret.

Secara garis besar (Bakar, 1981) membagi alat peraga menjadi dua:

1. Alat peraga yang bersifat perasaan, yaitu alat peraga yang berpengaruh dalam menguatkan pikiran dengan perantaraan benda-benda, dengan jalan menunjukkan bendanya sendiri atau contohnya atau gambarnya dan semacamnya.

2. Alat peraga yang bersifat bahasa, yaitu alat peraga yang mempengaruhi kekuatan pikiran dengan perantaraan lafal-lafal (kata-kata) seperti penjelasan dengan menyebutkan contoh atau definisinya atau persamaan katanya.

Selanjutnya McKnow dalam (Rohani, 1997) menyebutkan fungsi media pembelajaran sebagai berikut:

a. Mengubah titik berat pendidikan formal, dari pendidikan yang menekankan pada 
Jurnal Ilmiah Mandala Education

http://ejournal.mandalanursa.org/index.php/JIME/index

terakreditasi Peringkat 4 (No. SK: 36/E/KPT/2019)

instruksional akademis menjadi pendidikan yang mementingkan kehidupan peserta didik

b. Meningkatkan motivasi belajar peserta didik

c. Memberikan kejelasan (clarification)

d. Memberikan rangsangan (stimulation)

Eysenck, dkk (t.t) dalam Slameto (2010:

170) menyatakan bahwa "motivasi sebagai suatu proses yang menentukan tingkatan kegiatan, intensitas, konsistensi, serta arah umum dari tingkah laku manusia". Slavin (1994) dalam Rifa ${ }^{\text {ee }}$ (2011: 159) mengemukakan bahwa "motivasi merupakan proses internal yang mengaktifkan, memandu, dan memelihara perilaku seseorang secara terusmenerus". "Motivasi merupakan suatu konstruk yang menjelaskan awal, arah, intensitas, dan kehadiran perilaku individu yang bertujuan" (Robbins (1996) dalam Sagala, 2010: 110).

Mc. Donald (t.t) dalam Hamalik (2013: 158) menyatakan bahwa "motivation is an energy change within the person characterized by affective arousal and anticipatory goal reaction". Motivasi adalah perubahan energi dalam diri (pribadi) seseorang yang ditandai dengan timbulnya perasaan dan reaksi untuk mencapai tujuan. Lebih lanjut lagi, pernyataan Mc Donald mengandung tiga elemen penting dalam motivasi. Tiga elemen tersebut antara lain:

1. Motivasi dimulai dari adanya perubahan energi dalam pribadi.

2. Motivasi ditandai dengan timbulnya perasaan affective arousal.

3. Motivasi ditandai dengan reaksi-reaksi untuk mencapai tujuan.

Media pembelajaran MONIPA merupakan alat peraga yang sangat sederhana dan siswa dalam bermainnya akan mengingat lebih lama materi tentang Nilia-Nilai Pancasila dalam Kehidupan sehari-hari sehingga akan meningkatkan pemahaman dan nilai prestasi siswa serta siswa akan termotivasi dan senang dalam belajar materi pembelajaran PKn
Vol. 7 No. 1. Januari 2021

p-ISSN: 2442-9511 e-ISSN: 2656-5862

\section{Kajian Empiris}

Penelitian yang relevan sebagai pendukung peneliti mengenai keefektifan model media pembelajaran Monopoli terhadap hasil belajar dan aktivitas siswa adalah:

Pengembangan Media Pembelajaran Monopoli untuk meningkatkan minat belajar geografi siswa oleh M Siskawati,P PujiatiJurnal Studi Sosial 2016.

Penggunaan Media Monopoli terhadap peningkatan kemampuan pemahaman konsep matematis peserta didik kelasV Sekolah Dasar.oleh Indhira Asih Vivi Yandari,Maya Kuswaty.Jurnal Pendidikan Sekolah Dasar 2017.

\section{METODE PENELITIAN Jenis Penelitian}

Penelitian ini merupakan penelitian tindakan kelas yang merupakan proses pengkajian masalah pembelajaran di dalam kelas melalui refleksi diri dalam upaya untuk memecahkan masalah tersebut dengan cara melakukan berbagai tindakan yang terencana dalam situasi nyata serta menganalisis setiap pengaruh dari perlakuan tersebut (Wina Sanjaya, 2009: 26).

Dalam penelitian ini menggunakan penelitian tindakan kelas yang kolaborasi maksudnya penelitian tindakan kelas yang dirancang dan dilaksanakan oleh seseorang dan bekerja sama dengan guru kelas dalam melaksanakan tindakan yang telah disepakati bersama. Masalah yang didapat tidak dari guru secara langsung, akan tetapi masalah yang bersifat umum yang ditentukan oleh tim peneliti, walaupun sebenarnya dilakukan untuk membantu guru dalam meningkatkan kualitas pembelajaran. Penelitian ini digunakan untuk meningkatkan pemahaman dan hasil belajar siswa serta meningkatkan motivasi belajar subjek dengan menggunakan media pembelajaran MONIPA yang dirasa memiliki beberapa kelebihan.

Subjek Penelitian

Subjek dalam penelitian adalah siswa kelas VI SDN I Keresek Tahun Pelajaran 2018- 
Jurnal Ilmiah Mandala Education

http://ejournal.mandalanursa.org/index.php/JIME/index

terakreditasi Peringkat 4 (No. SK: 36/E/KPT/2019)
2019 yang terdiri dari 47 siswa dimana 20 siswa laki-laki dan 27 siswa perempuan

\section{Desain Penelitian}

Penelitian Tindakan klas ini menggunakan rancangan penelitian tindakan yang dikembangkan Kemmis dan Taggart (Wijaya Kusumah dan Dedi Dwitagama, 2011: 20), berupa siklus atau putaran. Model yang dikemukakan Kemmis dan Taggart berupa perangkat yang terdiri dari empat komponen, yaitu perencanaan, tindakan, observasi dan refleksi. Berikut bagan model penelitian yang dikembangkan oleh Kemmis dan Taggart dalam Wijaya Kusumah dan Dedi Dwitagama (2011:20):

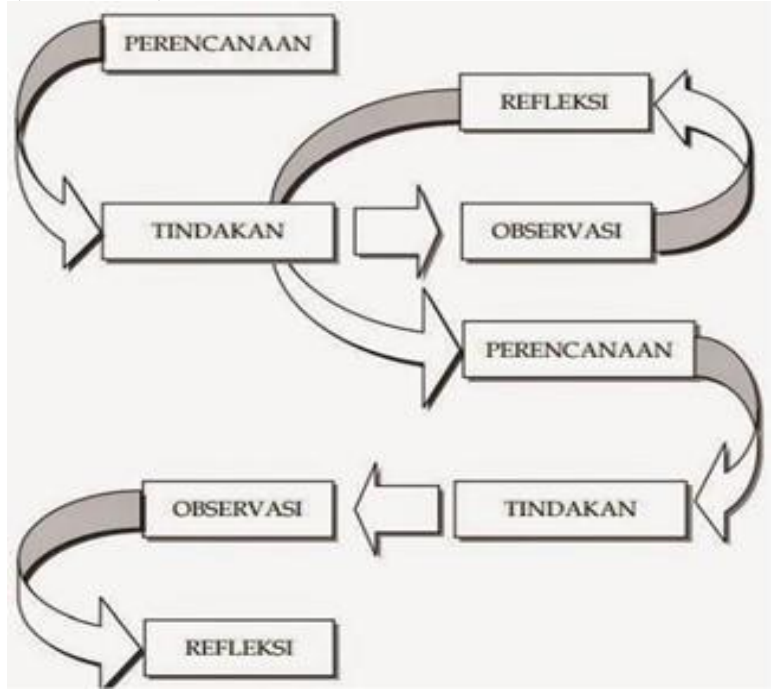

Gambar 1. Model Penelitian Tindakan Kelas

Menurut Wina Sanjaya (2009, 78 - 80) langkah-langkah pelaksanaan penelitian tindakan kelas terdiri dari perencanaan, pelaksanaan, observasi dan refleksi. Penelitian ini dilakukan dalam bentuk siklus. Secara rinci langkah-langkah dalam setiap siklus dijabarkan sebagai berikut.

\section{Perencanaan}

Perencanaan dalam penelitian ini terjadi dua proses yaitu perencanaan awal dan lanjutan. Pada perencanaan awal diturunkan dari asumsi perbaikan hasil dari kajian studi pendahuluan, sedangkan perencanaaan lanjutan, yaitu disusun berdasar hasil refleksi setelah peneliti mempelajari kelemahan yang harus diperbaiki.
Didalam tahap perencanaan, peneliti dan guru membuat rencana tindakan yang akan dilaksanakan dalam penelitian ini, yaitu: Menetapkan jadwal pelaksanaan penelitian tindakan kelas. Penelitian diadakan berdasarkan jadwal mata pelajaran PKn kelas VI SDN I Keresek.

- Membuat Rencana Persiapan pembelajaran yang disesuaikan dengan kurikulum 2013.

- Berdiskusi tentang media MONIPA dan penerapannya di dalam kelas.

- Menyusun Rencana Pelaksanaan Pembelajaran (RPP) dengan menggunakan media MONIPA dalam materi pelajaran PKn.

- Membuat lembar pengamatan untuk memantau aktivitas guru dan siswa dalam proses pembelajaran.

- Membuat skala untuk mendapatkan data awal mengenai motivasi belajar siswa terhadap motivasi belajar siswa terhadap mata pelajaran PKn.

\section{Pelaksanaan tindakan}

Langkah atau tahapan pada pelaksanaan ditahap ini yaitu melaksanakan tindakan sesuai dengan RPP yang telah dibuat menggunakan media MONIPA. Tindakan yang dilakukan sesuai dengan fokus masalah, sebagai upaya meningkatkan peahaman dan hasil belajar serta motivasi belajar siswa dalam mata pelajaran PKn.

\section{Observasi}

Pada Kegiatan observasi ini peneliti melakukan pengumpulan informasi tentang proses pembelajaran yang dilakukan guru dan siswa sesuai dengan tindakan yang telah disusun. Pengamatan ini dilakukan oleh 2 orang yang telah ditunjuk oleh peneliti. Observer akan melakukan pengamatan dengan menggunakan lembar observasi berupa daftar kegiatan dengan memberikan tanda centang $(\sqrt{ })$. Hasilnya dapat dijadikan masukan untuk guru melakukan refleksi untuk penyusunan rencana ulang memasuki putaran atau siklus berikutnya.

\section{Refleksi}

Kegiatan refleksi adalah aktivitas evaluasi terhadap hal-hal yang terjadi yang 
dilaksanakan guru selama tindakan. Refleksi dilakukan dengan mengkaji dari data observasi dan skala yang telah didapat sebelumnya. Data observasi mengacu pada keberhasilan penggunaan media film yang dapat dilihat dari respon siswa saat kegiatan pembelajaran. Data skala dan observasi digunakan untuk merefleksi hasil peningkatan motivasi belajar siswa. Hasil refleksi tersebut, guru dapat mencatat kekurangan yang perlu diperbaiki, sehingga dapat dijadikan dasar untuk perencanaan ulang pada siklus II. Tahapan pada siklus II juga diawali melalui perencanaan, tindakan, observasi dan refleksi. Siklus akan terus berjalan jika belum ada peningkatan pemahaman dan hasil belajar siswa serta motivasi belajar siswa sesuai dengan kriteria keberhasilan yang telah ditetapkan, tetapi jika sudah ada peningkatan pemahaman dan hasil belajar serta motivasi belajar siswa, maka siklus dihentikan.

\section{Rancangan}

Media pembelajaran MONIPA merupakan media pembelajaran yang sangat sederhana dimana mulai alat,bahan dan cara kerjanyapun sangat sederhana, sehingga di semua pelosok negeri bisa membuatnya.

a. Alat dan Bahan

\begin{tabular}{|l|l|}
\hline \multicolumn{1}{|c|}{ ALAT } & \multicolumn{1}{|c|}{ BAHAN } \\
\hline $\begin{array}{l}\text { Gunting, kater, } \\
\text { penggaris, } \\
\text { pinsil, hekter }\end{array}$ & $\begin{array}{l}\text { Kardus, kertas warna, lem, } \\
\text { karton,dadu,kotak } \\
\text { kecil,Gambar gambar } \\
\text { sesuai sila dari pancasila. }\end{array}$ \\
\hline
\end{tabular}

Tabel 1 alat dan bahan

b. Cara Membuatnya

1. Persiapkan Kardus yang agak besar kemudian gunting dengan rapi sesuai ukuran yaitu 40 x $40 \mathrm{~cm}$.

2. Lapisi Kardus dengan karton biar kelihatan bagus dan rapi dengan cara di lem

3. Kardus tersebut diberi kotak kotak untuk menyimpan pertanyaan dan gambar

4. Siapkan kertas warna gunting sesuai selera berbentuk persegi

5. Kertas warna dibagi dua ada yang ditulisi dengan kata kata pertanyaan dan ada juga dilapisi gambar gambar yang sesuai dengan pengamalan pancasila.

6. Membuat dadu dari sendal bekas berbentuk kubus kemudian di beri mata dadu dari nomor 1 sampai 6

7. Buat kotak kecil dari karton berbentuk kubus terbuka untuk tempat mengocok dadu saat permainan.

\section{A. Cara menggunakan Alat dalam pembelajaran}

1. Siswa Berkelompok sekitar 6-7 orang perkelompoknya,tiap kelompok ada tutornya yang sudah mengerti tentang materi Nilai-Nilai Pancasila dalam kehidupan sehari-hari.

2. Sesudah disiapkan Monopolinya yang jadi tutor untuk mengontrol jawaban siswa lain benar atau salahnya.

3. Siswa lain bermain secara bergantian dimana awalnya mulai mengocok dadu kemudian sudah dapet kocokan berapa anak maju sesuai hitungan dari stra ke kanan nanti sampai dimana sesuai jumlah kocokan kemudian pas kocokan sampai pada kotak berapa laksanakan sesuai perintah dari monopoli.

4. Setiap Perintah harus dijawab oleh pemain kalau jawaban benar nanti ada poinnya oleh tutornya kalau salah dikurangi poinnya karena awalnya diberi dulu poin masing masing 100 kalau jawaban benar nambah poin kalau salah akan mengurangi poin.

5. Kemudian permainan bergantian sampai selesai samapi kartu pertanyaan habis. Setiap regu ada 30 pertanyaan.

6. Pemenangnya yang jumlah poinnya banyak atau besar

7. Sesudah beres permainan siswa yang paling besar poinnya atau juaranya mempresentasikan hasil jawabannya di depan kelas yang lain yang mendapat soal yang sama untuk mengoreksi jawabannya kemudian membuat jawaban yang benarnya jadi mengganti 
jawaban yang salah menjadi jawaban yang benar.

8. Dalam permainan MONIPA ini anak aktif,kreatif dan pembelajaran menjadi menyenangkan,anak juga belajar menyampaikan hasil jawabannya didepan kelas ini untuk mengajar siswa berani mengemukakan pendapatnya didepan umum dan belajar berbicara.

Dengan adanya pembelajaran menggunakan MONIPA nilai hasil ulangan siswa kelas VI dari siswa 47 orang dengan KKM 71 ada peningkatan dibanding sebelum menggunakan MONIPA.

Tabel 2. Klasifikasi Kemampuan hasil ulangan siswa pada Siklus 1

\begin{tabular}{|c|c|c|c|c|}
\hline No & Nilai & Kategori & Frekuensi & Presentase \\
\hline 1 & $86-100$ & Sangat & - & - \\
\hline 2 & $71-85$ & Baik & 15 & 31,9 \\
\hline 3 & $56-70$ & Baik & 10 & 21,3 \\
\hline 4 & 41-55 & Cukup & 22 & 46,8 \\
\hline 5 & $<40$ & $\begin{array}{l}\text { Kurang } \\
\text { Kurang } \\
\text { Sekali }\end{array}$ & - & \\
\hline & Juml & & 47 & 100 \\
\hline
\end{tabular}

Berdasarkan tabel diatas siswa yang tuntas dari KKM 71 adalah

Tabel 3 Kategori ketuntasan belajar siswa pada Siklus I

\begin{tabular}{|l|l|l|l|}
\hline Nilai & Kategori & Frekuensi & Persen \\
\hline$\geq 71$ & Tuntas & 15 & 31,9 \\
$<70$ & Belum tuntas & 32 & 68,1 \\
\hline
\end{tabular}

Berdasarkan tabel ketuntasan di atas, maka ketuntasan klasikal berdasarkan KKM pada siklus I baru mencapai 31,9 \% dan belum mecapai indikator yang ditentukan yaitu $80 \%$ sehingga dilanjutkan pada siklus II.

Pada siklus II hasil kemampuan siswa juga diklasifikasikan seperti pada siklus I dapat dilihat pada Tabel 4.

Tabel 4 Klasifikasi Kemampuan siswa pada Siklus II

\begin{tabular}{lllll}
\hline No & Nilai & Kategori & Frekuensi & Presentase \\
\hline 1 & $86-100$ & Sangat Baik & 23 & 48,93 \\
2 & $71-85$ & Baik & 20 & 42,55 \\
3 & $56-70$ & Cukup & 4 & 8,52 \\
4 & $41-55$ & Kurang & - & - \\
5 & $<40$ & Kurang Sekali & - & - \\
Jumlah & & & 47 & 100
\end{tabular}

Berdasarkan tabel diatas maka presentasi ketuntasan belajar pada siklus II dapat dikatagorikan berdasarkan KKM yang berlaku di sekolah tempat penelitian untuk mata pelajaran PKn dapat dilihat pada tabel 5 .

Tabel 5 Kategori ketuntasan belajar siswa pada Siklus II

\begin{tabular}{llll}
\hline Nilai & Kategori & Frekuensi & Persen \\
\hline$\geq 71$ & Tuntas & 43 & 91,48 \\
$<70$ & Belum tuntas & 4 & 8,52 \\
\hline
\end{tabular}

Berdasarkan tabel ketuntasan di atas, maka ketuntasan berdasarkan KKM pada siklus II mencapai $91,48 \%$ sudah melebihi indikator yang ditentukan yaitu $80 \%$ sehingga penelitian dicukupkan sampai siklus II.

Jika kita bandingkan rata-rata kemampuan siswa pelajaran PKn Materi Nilai-Nilai pancasila dalam kehidupan sehari-hari melalui penerapan metode Diskusi kelompok dan menggunakan media MONIPA antara siklus I dan siklus II maka dapat dilihat pada

Perbedaan hasil siswa antara siklus I dan II sangat signifikan sekali oleh karena itu alat peraga MONIPA sangat baik digunakan di sekolah.

\section{B. Foto Proses pembuatan dan pelaksanaan Kegiatan}
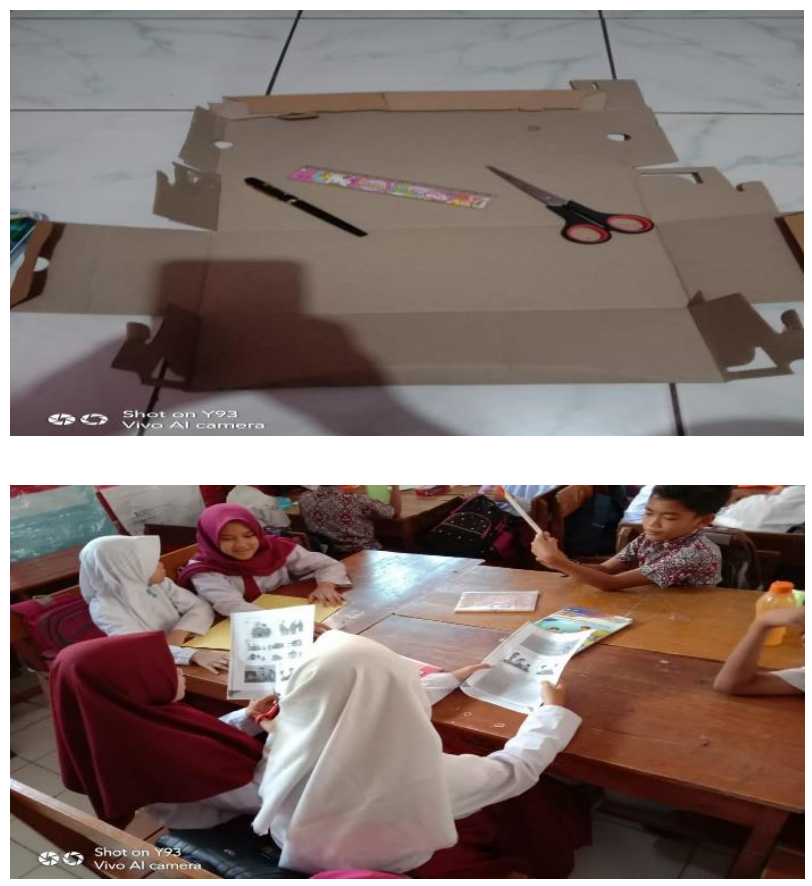

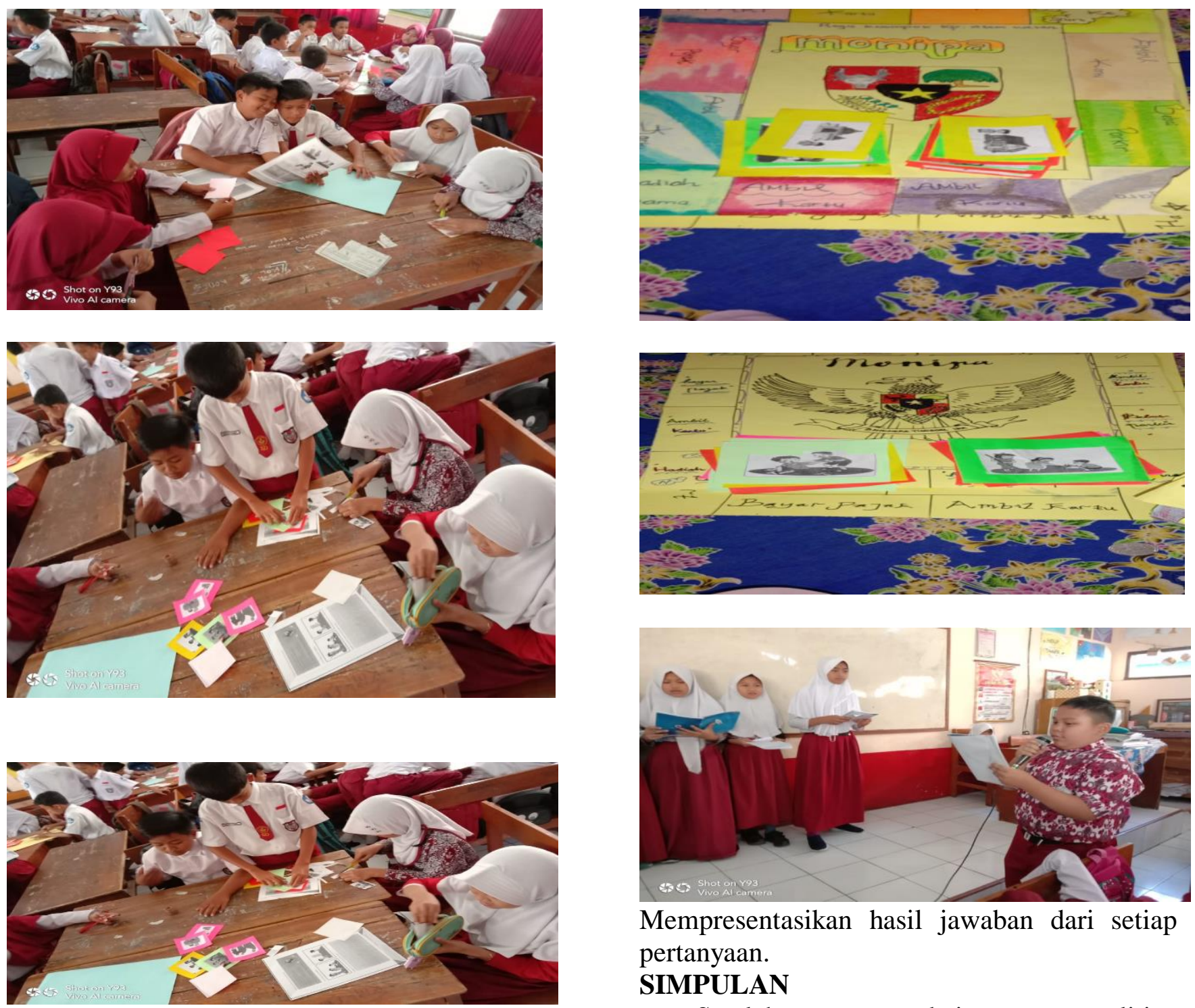

Mempresentasikan hasil jawaban dari setiap pertanyaan.

\section{SIMPULAN}

Setelah serangkaian penelitian

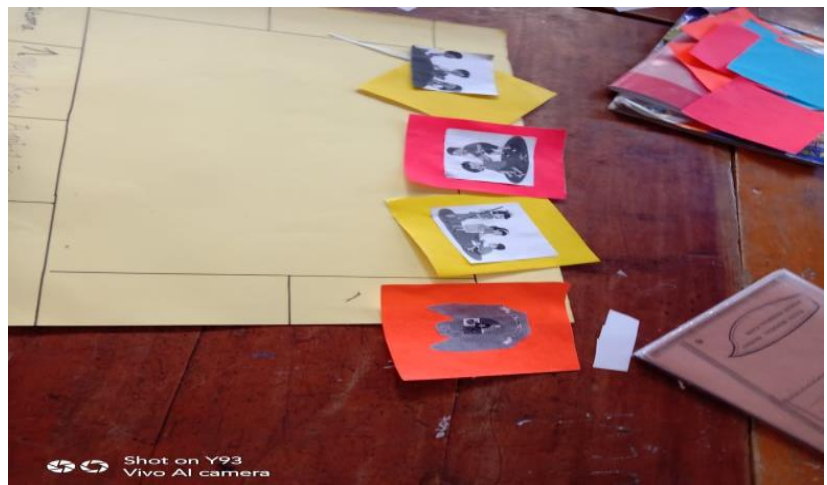

pengggunaan alat peraga MONIPA dilakukan dapat ditarik simpulan sebagai berikut:

1. Penggunaan alat peraga MONIPA dapat meningkatkan pemahaman materi pengamalan Nilai-Nilai Pancasila dalam kehidupan sehari-hari

2. Alat peraga MONIPA dapat meningkatkan hasil pembelajaran.

3. Penggunaan alat peraga MONIPA dapat meningkatkan aktifitas siswa dan memunculkan sikap/prilaku positif siswa dalam pembelajaran. 


\section{SARAN}

Selanjutnya sebagai tindak lanjut

penelitian disarankan:

1. Upaya perbaikan berbagai elemen penunjang meningkatnya prestasi dan aktifitas belajar siswa

2. Guru lebih termotivasi dan harus terus berinovasi untuk mengembangkan dan membuat media pembelajaran,agar siswa mudah memahami materi pembelajaran.

\section{DAFTAR PUSTAKA}

Abdurrahman,M.(2009). Pendidikan Bagi Anak kesulitan Belajar,Jakarta; PT. Asdi Mahasatya.

Arianto.(2018). Penerapan Model pembelajaran Terpadu Untuk Meningkatkan Keterampilan Menyimak dan Berbicara Siswa kelas IX-2 SMPN 17 Kendari, Kendari: Jurnal hasil Penelitian.

Asih Vivi Yandari Indhira ( 2017). Media Monopoli terhadap Peningkatan kemampuan pemahaman konsep Matematis peserta didik Kelas V sekolah Dasar, Jakarta; Jurnal pendidikaan.

Fatkoer Rohman,Moch.(2018). Karya Inovasi Pembelajaran Guru Jenjang Pendidikan Menengah Tingkat Nasional, Lombok Utara: Jurnal hasil penelitian.

Setiawan denny,dkk. (2008). Komputer dan Media Pembelajaran, Jakarta: Universitas Terbuka.

Wardani, I. G. A. K, dkk.(2007). Penelitian Tindakan Kelas, Jakarta : universitas Terbuka.

Winataputra, Udin..S,dkk. (2007). Teori Belajar dan Pembelajaran, Jakarta: UniversitasTerbuka. 